\section{Radical History}

\section{Editorial Secretary}

Marjorie Murphy, Swarthmore College

Published for MARHO: The Radical

Historians' Organization

Radical History Review presents innovative scholarship and commentary that looks critically at the past and its historians from a nonsectarian left perspective. $R H R$ scrutinizes conventional history and seeks to broaden and advance the discussion of crucial issues such as the role of race, class and gender in history. The journal offers original articles; review essays that examine the uses and abuses of history in the popular media, film, history museums and other public forums; and interviews with leading radical historians. Each volume is illustrated with drawings, cartoons, photographs and other graphic art. Issues are often thematic and cover a wide range of geographic areas and subjects. Volume 58 will be devoted to "Latin American Labor".

Triannual (ISSN 0163-6545)

Volume 58 - 60, 1994

Institutions $\$ 50.00$; Individuals $\$ 25.00$.

Single Parts $\$ 18.00$.

\section{Send orders to:}

Cambridge University Press

40 West 20th Street

New York, NY 10011-4211

(Outside the USA, Canada, or Mexico:

Cambridge University Press, The Edinburgh Building

Shattesbury Road, Cambridge CB2 2RU, England.)

\section{CAMBRIDGE UNIVERSITY PRESS}

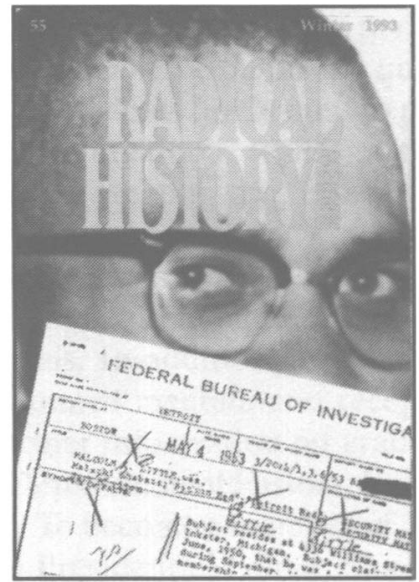




\section{Popular Mobilization in Mexico}

The Teachers' Movement, 1977-87

\section{Joe Foweraker}

This book explores the process of popular political mobilization in contemporary Mexico through the experience of the country's most important popular organizationthe teachers' movement.

44147-1 Hardcover $\$ 59.95$

\section{The Politics of Work}

Gender and Labour in

Victoria, 1880-1939

Raelene Frances

This study is concerned with the complex relationship between economic and technological change, nature of sexual division in the workforce, and the role of union, employer and state activists. 40199-2 Hardcover $\$ 59.95$

Now in paperback Visions of the People Industrial England and the Question of Class, c. 1848-1914 Patrick Joyce

"The most substantial and sustained attempt yet to go beyond the ortbodoxy of class... its achievement should be welcomed and celebrated."

-Journal of Historical Geograpby 44797-6 Paper about $\$ 21.95$

\section{The Political Economy of Shopkeeping in Milan, 1886-1922} Jonathan Morris

This book analyzes the business, geography and politics of shopkeeping in Milan between 1886 and 1922 . This is the first full-scale study of any aspect of the experience of the Italian petite bourgeoisie in the pre-Fascist period. 39119-9 Hardcover $\$ 64.95$

\section{Common Labour}

Workers and the Digging of

North American Canals,

1780-1860

\section{Peter Way}

This study of canal construction workers between 1780-1860 challenges labor history's focus on skilled craftsmen. Canalers were unskilled workers, often members of despised social groups such as Irish immigrants and AfricanAmerican slaves. Lacking the power that skill brought, canalers had little control over their working conditions. Their experiences represent a different strand of the labor story.

44033-5 Hardcover $\$ 54.95$

Now in paperback...

\section{The London Hanged}

Crime and Civil Society in the Eighteenth Century Peter Linebaugh

"This is a magisterial book. Few recent works reflect as global an understanding of the eighteenth century and its people, and its unforgettable re-creations of London topography and colloquial language will belp to make it a classic."

45758-0 -American Historical Review

Reissued as a Canto paperback... The Wheelrights Shop George Sturt

Foreword by E. P. Thompson 44772-0 Paper $\$ 10.95$

Available in bookstores or from

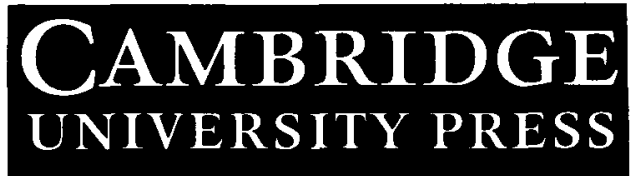

40 West 20th St., N.Y., NY 10011-4211

Call toll-free 800-872-7423

MasterCard/VISA accepted.

Prices subject to change. 


\section{LABOUR/LE TRAVAIL}

\section{Journal of Canadian Labour Studies}

Labour/Le Travail is the official publication of the Canadian Committee on Labour History. Since it began publishing in 1976, it has carried many important articles in the field of working-class history, industrial sociology, labour economics, and labour relations. Although primarily interested in a historical perspective on Canadian workers, the journal is interdisciplinary in scope. In addition to articles, the journal features documents, conference reports, an annual bibliography of materials in Canadian labour studies, review essays, and reviews. While the main focus of the journal's articles is Canadian, the review essays and reviews consider international work of interest to Canadian labour studies. Many of Labour's articles are illustrated.

\section{REVUE D'ÉTUDES OUVRIÈRES CANADIENNES}

Publiée par le Comité canadien sur l'histoire du travail, la revue Labour/Le Travail a fait parâtre depuis 1976 plusieurs articles marquants dans le domaine de l'histoire de la classe ouvrière, de la sociologie industrielle, de l'économie du travail et des relations industrielles. Bien qu'elle se propose d'abord d'étudier les travailleurs et les travailleuses du Canada dans une perspective historique, la revue est aussi ouverte aux spécialistes d'autres disciplines. En plus des articles, la revue publie des documents, des rapports de conférences, une bibliographie annuelle, des notes critiques et des comptes rendus de volumes. Si la plupart des articles touchent le Canada, les notes critiques et les comptes rendus portent sur des travaux d'envergure internationale pouvant intéresser les chercheurs canadiens. Des illustrations accompagnent plusieurs articles de Labour/Le Travail.

Subscribers for 1993 will receive/Les abonnés pour 1993 recevront:

Labour/Le Travail 31 (Spring/Printemps 1993) - articles by Rusty Bitterman, Christina Burr, Terry Wotherspoon, Ann Porter, and Ralph Peter Güntzel

Labour/Le Travail 32 (Fall/Automne 1993) - articles by Richard A. Rajala, W.J.C. Cherwinski, Joan Sangster, Gillian Creese, Donald Dennie, and Ellen Scheinberg.

\section{SPECIAL INTRODUCTORY OFFER/OFFRE SPÉCIALE}

While the supply lasts, new subscribers may purchase sets of the journal at a special bargain rate of $\$ 260.00$ (30 issues, 9818 pp., reg. $\$ 362$ ).

Avec tout nouvel abonnement, l'abonné peut aussi acquérir la série complète de la revue pour le prix modique de $260 \$$ tant que nos réserves d'anciens numéros ne soient pas épuisées (30 numéros, 9818 pp., reg. 362\$).

$\begin{array}{llr}\text { Individual/individu } & \text { Canada } & \text { Foreign/Étranger } \\ \text { Institutional/institution } & \$ 20.00 & \$ 30.00 \text { (US/EU) } \\ \begin{array}{l}\text { Student/étudiant } \\ \text { Retired/retraité }\end{array} & \$ 25.00 & \$ 35.00 \text { (US/EU) } \\ & \$ 15.00 & \$ 25.00 \text { (US/EU) }\end{array}$

Unemployed/sans-travail

(GST exempt / exempté du TPS)

MASTERCARD accepted or make cheque payable to: Canadian Committee on Labour History, History Dept., Memorial University, St. John's, NF, Canada A1C 5S7

Carte MASTERCARD acceptée ou chèque visé à l'ordre de: Comité canadien sur l'histoire du travail, Département d'histoire, Université Memorial, St. John's, T.-N., Canada, A1C 5S7

Articles are abstracted and indexed/Les articles sont répertoriés dans:

America: History and Life; Alternative Press Index; Arts and Humanities Citation Index ${ }^{\mathrm{TM}}$; Canadian Magazine Index; Canadian Periodical Index; Current Contents / Arts and Humanities; Historical Abstracts; Human Resource Abstracts; PAIS Bulletin; PAIS Foreign Language Index; Sage Public Administration Abstracts. 


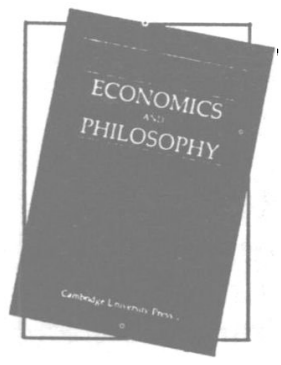

EDITORS:

Daniel M. Hausman, University of Wisconsin

Michael S. McPherson, Williams College

\section{Economics and Philosophy} explores the foundations of economics as both a predictive/ explanatory enterprise and a normative one. The papers examine the relevance of economic techniques, methods and conclusions to philosophical questions in ethics and social theory. The journal is designed to foster collaboration between economists and philosophers, and to bridge the increasingly artificial boundaries between them. Each issue contains review essays, detailed book reviews, and continuing discussion on topics previously covered.

\section{Economics and Philosophy}

Semi-annual (ISSN 0266-2671)

Volume 9, 1993

Institutions \$66.00; Individuals \$33.00. Single Parts $\$ 35$.00.

Send orders to: CAMBRIDGE UNIVERSITY PRESS, 40 West 20th Street, New York, NY 10011-4211. Outside the USA, Canada and Mexico:

CAMBRIDGE UNIVERSITY PRESS, The Edinburgh Building, Shaftesbury Road, Cambridge CB2 2RU, England

\section{Cambridge}

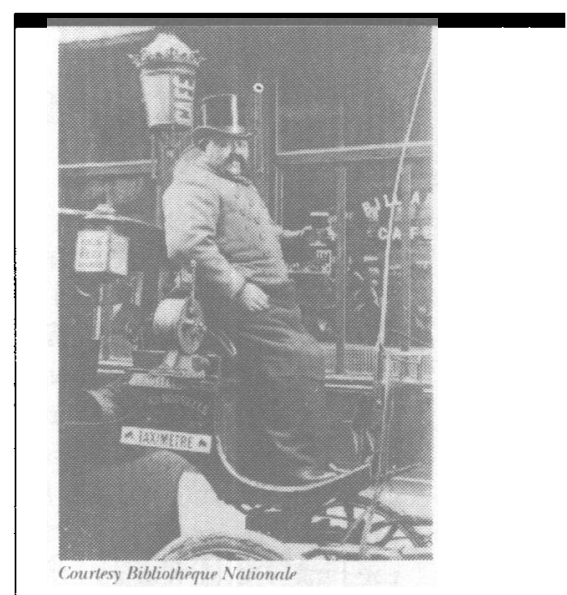

The Coachmen of Nineteenth-Century Paris

\section{Service Workers and Class Consciousness}

\section{Nicholas Papayanis}

In his captiwating new book, Nicholas Paparanis sets about to penetrate the popular image of nineteenth-century Parisian coachmen and present a realistic picture of this frequently maligned segment of the population. He offers both a definitive history of Paris cabbies, including a sociological portrait of these workers, and an economic and structural history of the Paris cab trade. The Coachmen of Nineteenth-Century Paris fills a gap in the literature dealing with Paris and its working class and tells the intriguing story of expanding public transportation in Paris.

November

$\$ 45.00$

\section{Louisiana State} University Press

\section{Baton Rouge 70803}




\section{Proletarians of The French the North \\ Worker}

Mexican Industrial

Workers in Detroit and the Midwest, 1917-1933 ZARAGOSA VARGAS

"A well-documented and persuasive description of the experiences and aspirations of the thousands of Mexicans who migrated to the Midwest in search of employment between the First World War and the Great Depression."--David Montgomery, Yale University Latinos in American Society and Culture $\$ 40.00$ cloth, illustrated

Autobiographies from the Early Industrial Era Edited, Translated, and with an Introduction by MARK TRAUGOTT

Here is a rare glimpse of the everyday lives of workers in the age of early industrialization in France. Appearing for the first time in English, these stories vividly convey the ambitions, hardships, and reversals of ordinary people struggling to gain a measure of respectability.

$\$ 50.00$ cloth, $\$ 16.00$ paper, illustrated

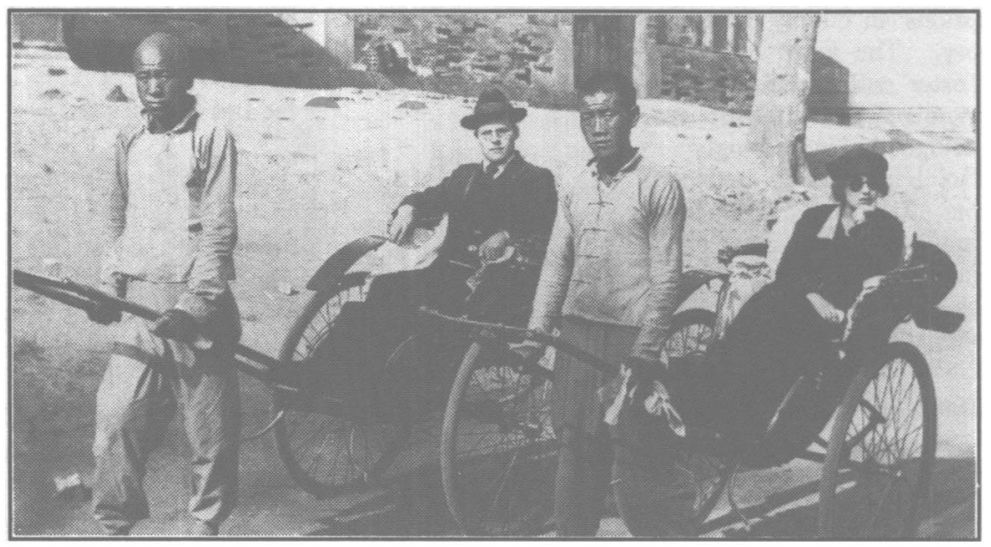

\section{Rickshaw Beijing}

City People and Politics in the 1920s

\section{DAVID STRAND}

New in paper-"Strand takes us into a part of urban China in the 1920 s that we have not seen before, and provides an admirable addition tothe studies of the urban workforce." $\$ 15.00$ paper, illustrated Winner, Joseph Levenson Prize
At bookstores or order woll-free 1-800-822-6657.

\section{University of California Press}

Berkeley

Los Angeles

New York

London

1893

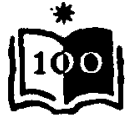




\section{International Labor and \\ Working-Class History}

\section{Subscription Order Form}

ISSN 0147-5479 (Semi-annual)

Numbers 43-44, 1993

Numbers 45-46, 1994

口 Individuals US\$18 (UKf14)

口 Individuals US\$18 (UK£14)

口 Institutions US\$36 (UKf28)

D Institutions US\$36

(UK£28)

Please send me the following back issues (inst: $\$ 20.00 / £ 15$, ind.: $\$ 10.00 / £ 7.50$ ):

Prices good through December 31, 1994. Prepayment is required.

Name Date
Subscription:

Back issue(s): Can. add $7 \%$ GST:

Total: $\$ / \mathfrak{E}$

Address

In the U.S., Canada and Mexico payment may be made in US dollars or the equivalent in Canadian dollars. (Canadians must add 7\% GST.) Checks, VISA, MasterCard and money orders are accepted.

Outside these countries payment may be made in UK $f$, using: cheque (payable to Cambridge University Press and drawn against a UK bank); Eurocheque in Sterling; Intemational Money Order, Bank Draft; Post Office Giro (A/C No. 5716055 Bootle); Credit Card -- VISA, MasterCard and American Express.

Card Type

Card Number Expiration

Signature

Please state address as registered with credit card company if different from above:

In the US, Canada and Mexico send orders to: Cambridge Univ. Press, 40 West 20th St., New York, NY, 10011-4211, USA. Tel: 1-800-431-1580, ext. 154 Fax: 914-937-4712.

Outside these countries send orders to: Journals Marketing Dept., Cambridge Univ. Press, The Edinburgh Building, Cambridge CB2 2RU, UK. Tel: +44 (0)223 325806 Fax: +44 (0)223 315052. 


\section{Back Issues Available! \\ International Labor and Working-Class History}

No. 42, Fall 1992/SPECIAL ISSUE: "Tradition and the Working Class," Louise Tilly, Noëlle Gérôme, Mary Blewett, Geoffrey Field, Larry Peterson, Gottfried Korff, Lizabeth Cohen

No. 41, Spring 1992: Scholarly Controversy -- "The Name of the Father: Women, Paternity, and British Rule in Nineteenth Century Jamaica," Persis Charles, Catherine Hall, Thomas C. Holt, Dale Tomich

No. 40, Fall 1991/SPECIAL ISSUE: "Labor and the Welfare State," James E. Cronin, Peter Weiler, Miriam Cohen, Michael Hanagan, George Steinmetz

No. 39, Spring 1991: Scholarly Controversy -- "The Proletarian Family," David Levine, William H. Sewell, Jr., Thomas Dublin, John Gillis

No. 38, Fall 1990/SPECIAL ISSUE: The "Working Class in World War II," Geoffrey Field, Richard Rice, Janet Hart

No. 37, Spring 1990: Scholarly Controversy -- "The End of Mass Culture," -- Michael Denning, Janice Radway, Luisa Passerini, William R. Taylor, Adelheid von Saldern

No. 36, Fall 1989: Scholarly Controversy -- "New Tendencies in the History of Labor and the Working Class in Latin America," Emilia Viotti da Costa, Barbara Weinstein, Perry Anderson, Hobart A. Spalding, June Nash

No. 35, Spring 1989: "War and Society in Soviet Context: Soviet Labor before, during and after World War II," Article by Sheila Fitzpatrick

No. 34, Fall 1988/SPECIAL ISSUE: "Religion and the Working Class," Michael F. Jiménez, John Bukowczyk, Ken Fones-Wolf, Anna Clark

No. 33, Spring 1988: "Foreign Workers in Soviet Russia, 1920-40: Their Experience and their Legacy," Review essay by Andrea Graziosi

No. 32, Fall 1987: Scholarly Controversy -- "American Workers in the 1920s," David Montgomery, Charles S. Maier, Susan Porter Benson

No. 31, Spring 1987: Scholarly Controversy -. "On Language, Gender, and Working-Class History," Joan W. Scott, Bryan D. Palmer, et. al.

No. 30, Fall 1986/SPECIAL ISSUE: "The Popular Front," Martha A. Ackelsberg, Herrick Chapman, Irwin M. Wall, Michael Honey, Bruce C. Nelson, Gary Cross

No. 29, Spring 1986/SPECIAL ISSUE: "The Haymarket," Bruce C. Nelson, Hartmut Keil, Marjorie Murphy, Raymond C. Sun, J.H.M. Laslett, et. al.

No. 28, Fall 1985: Scholarly Controversy -- "Labor's Way: On the Successes and Limits of Socialist Politics in Interwar and Post-World War II Germany," David Abraham, Geoffrey Eley, Leo Panitch, Dick Geary 


\section{INTERNATIONAL LABOR AND WORKING-CLASS HISTORY}

To Appear in Forthcoming Issues of $\mathrm{ILWCH}$

\section{Articles}

Drinking and the Working Class

In France, Germany, Britain, the United States, and Sweden

The Future of Working-Class History

Results of a roundtable discussion sponsored by ILWCH's Board of Editors

Worker Internationalism and Italian Labor Migration

Papers from the Paris Colloquium on Workers \& Citizenship in Europe \& North America During the 19th \& 20th Centuries

\section{Review Essays}

Racism in the United States

Chicano Labor History

Prostitution and the Working Class

Revised Index to all volumes 


\section{INTERNATIONAL LABOR AND \\ WORKING-CLASS HISTORY}

NUMBER 44

FALL 1993

\section{SCHOLARLY CONTROVERSY}

Race and the CIO: The Possibilities for Racial Egalitarianism

During the 1930s and 1940s

Michael Goldfield

Response: Working-Class Racism: Broaden the Focus

Gary Gerstle

Response: The Possibilities for Racial Egalitarianism: Context Matters

Robert Korstad

Response: Beyond Theoretical Models: The Limited Possibilities

for Racial Egalitarianism

Marshall F. Stevenson

Response: The Ins and Outs of the CIO

Judith Stein

\section{ARTICLE}

"Keeping the Natives Under Control": Race Segregation and the Domestic Dimensions of Empire, 1920-1939

Laura Tabili

\section{REVIEW ESSAY}

Homo Faber-Homo Ludens: Sport History and the Working Class

Patrick B. Miller

\section{FOREIGN EDITOR'S REPORT: THE NETHERLANDS}

Long-term Continuities in Labor History: The Case of the Dutch Republic Marcel van der Linden

REPORTS AND CORRESPONDENCE

RESEARCH REPORT

BOOK REVIEWS 